3. Посібник модулювання ефективної фінансової діяльності органів місцевого самоврядування ОТГ в умовах децентралізації. Консолідований підхід. URL: https:/www.ua.undp.org/content/dam/ ukraine/docs/Donbas/RPP/UA-UNDP-financial-operations-for-local-govATC-1.pdf. (дата звернення 18.02.2021).

4. Ясміна Джикіч (Jasmina Djikic). Фінансова децентралізація та реформа фінансів органів місцевого самоврядування. URL: http://sklinternational.org.ua/wp-content/uploads/2018/10/PolicyBrief-UKR.pdf. (дата звернення 18.02.2021).

DOI https://doi.org/10.30525/978-9934-26-045-2-28

\title{
ADVANTAGES OF USING INTERNATIONAL INFORMATION SYSTEMS FOR CUSTOMS RISK MANAGEMENT IN UKRAINE
}

\author{
Razumei H. Yu. \\ Ph.D. in Public Administration, \\ Associate Professor at the Department of Public Governance \\ and Customs Administration \\ University of Customs and Finance \\ Dnipro, Ukraine
}

Razumei M. M.

Ph.D. in Public Administration, Associate Professor at the Department of International Economic Relations, Regional Studies and Tourism University of Customs and Finance Dnipro, Ukraine

The functional role of Customs includes the demands of the international community to the customs administrations in the twenty-first century and the conventional mission of Customs: «to develop and implement an integrated set of policies and procedures that ensure increased safety and security, as well as effective trade facilitation and revenue collection» $[1$, p. 5].

That is why risk management was defined as the main philosophy of customs control in the revised Kyoto Convention [2]. D.Widdowson noticed that the Information management focus is one of the main factors of 
Compliance Assessment in his Risk-based Compliance Management Pyramid [3, p. 46]. The World customs organization (hereinafter - WCO) is dedicating 2019 to the swift and smooth cross-border movement of goods, people and means of transport, with the slogan «SMART borders for seamless Trade, Travel and Transport.» This imperative provided the reengineering of customs business processes while applying new technologies to «smartly» achieve an interconnected global value chain that fosters economic growth in an inclusive manner. This concept is following the guiding principles for SMART borders, namely: Secure, Measurable, Automated, Risk Management-based and Technology-driven [4]. Three last of them are vital for building innovative customs agency in each country that fits the fast changes of the modern word.

In the European Union the use of customs risk management is established in the Union Customs Code and EU Customs Blueprints. Therefore much attention is paid to customs risk management in the Association Agreement between the European Union and its Member States, and Ukraine. Provisions of Association Agreement chapter 5 'Customs and trade facilitation' set that EU and Ukraine respective trade and customs legislation shall be stable and comprehensive [5].

At the legislative level the use of risk management systems during the selection of customs control forms was defined in 2012 in chapter 52 'Risk Management System' of the current Customs Code of Ukraine [6]. But the history of customs risk management implementation began yet in 2005 from the adoption of conception in this field. In 2007 the Automated Risk Analysis and Management System (ARAMS), has been integrated into the Ukrainian customs database «Inspector» that created an automated approach to choose high risk movements at the border. For this purpose such risk management instruments as risk indicators and profiles, orientation, random selection are used automatically.

Also, Ukrainian customs officers distinguish the fiscal risks and nonfiscal risks (risks of safety) [7]. Fiscal risks are risks, the identification of which are aimed at preventing the minimization of the payment of taxes and fees, customs and other payments in the implementation of foreign economic operations. Non-fiscal (security) risks are the risks, the identification of which are aimed at ensuring the protection of national security, life and health of people, animals, plants, the environment, and the interests of consumers.

O. Komarov [8, p. 39] defines the risk management system as a set of instruments of automated, manual and combined customs controls, based on the principle of selectivity within the scope of customs control required to ensure compliance with customs law. 
ARAMS allows creating risk profiles of arbitrary complexity using such innovative approaches as fuzzy logic algorithms and taking into account the positive and negative history of prior customs clearance. That makes it a very flexible instrument for regional customs bodies.

Nowadays the perspective of Ukrainian ARAMS development is the implementing the National Customs Enforcement Network (hereinafter nCEN) of WCO and the European transit system, the New Computerised Transit System (hereinafter - NCTS) to enhance the effectiveness of national customs risk management.

The nCEN software will enable the State Customs Service of Ukraine to efficiently collect, store, analyze and disseminate law enforcement intelligence at the national level in order to enhance the operational capabilities of the Customs, as well as to improve risk profiling at the strategic, tactical and operational levels. This includes schematising the risks and groups of goods, routes and trading companies that are potentially exposed to the violation of customs rules.

The use of nCEN will facilitate a more active exchange of information between customs authorities at the regional and international levels, enhance cooperation between all sectors of the border. The nCEN consists of three independent databases. The principal database of national seizures and offences comprises data required for analysis, as well as means of conveyance, routes, and the possibility to view photos depicting exceptional concealment methods. Two supplementary databases contain information on suspicious persons, methods of conveyance and business entities of interest to Customs, thereby facilitating a structured investigation process [9].

The NCTS system is a pan-European computerized transit cargo management system. The main goal of the creation of NCTS is the integration of the customs systems of Europe, as well as the almost complete abolition paper workflow for transit traffic between countries [10].

The advantage of NCTS increased efficiency of controlling procedures for transited goods via advance submitted information with further its risk analysis before the arrival of goods, usage of the IT system guarantee system and transit simplifications for reliable companies (authorised consignee, authorised consignor, comprehensive guarantee, etc).

The business community of Ukraine considers that the exchange of information in real-time will resolve the issues of the customs value confirmation, which remains a problematic aspect of the relationship between the business and customs authorities and overcoming corruption at customs [11].

In 2020 the Cabinet of Ministers of Ukraine adopted final Resolution [12], which approves a number of standard documents and enables the 
customs authorities of Ukraine to exchange information with 35 countries in real-time.

Thus implementing this information system in customs control in Ukraine is the main step to simplify customs formalities and to to enhance national and international security via customs risk management system filled with more sophisticated data for analysis.

\section{References:}

1. Customs in the 21st century. Enhancing Growth and Development through Trade Facilitation and Border Security / WCO. 2008. URL:http://www.wcoomd.org/files/1.Publicfiles/PDFandDocuments/ AnnexII-Customs in the 21st Century.pdf (access date: 26.02.2021).

2. International Convention on the Simplification and Harmonization of Customs Procedures (as amended) / WCO. 1999. URL: http://www.wcoomd.org/Topics/Facilitation/Instrument\%20and\%20 Tools/Conventions/ pf_revised_kyoto_conv/Kyoto_New (access date: 26.02.2021).

3. Widdowson D. Intervention by Exception: A Study of the use of Risk Management by Customs Authorities in the International Trading Environment: a thesis submitted in fulfilment of the requirements degree of Doctor of Philosophy. University of Canberra. 2003. 310 p.

4. International Customs Day 2019. URL: http://www.wcoomd.org/ en/about-us/international-customs-day/previous-editions/icd-2019.aspx (access date: 26.02.2021).

5. Association Agreement between the European Union and its Member States, of the one part, and Ukraine, of the other part. 2014. URL: https://eeas.europa.eu/sites/eeas/files/association_agreement_ukraine_ 2014_en.pdf (access date: 26.02.2021).

6. Customs Code of Ukraine / Verkhovna Rada of Ukraine. URL: https://zakon.rada.gov.ua/laws/show/4495-17 (access date: 27.02.2021).

7. On approval of the Order of risk analysis and assessment, development and implementation of risk management measures for determination of forms and scope of customs control : Decree from 31 July, 2015, No. 684 / Ministry of Finance of Ukraine. URL: https://zakon.rada.gov.ua/laws/show/z1021-15 (access date: 27.02.2021).

8. Komarov. O. Risk management systems in Customs: the Ukrainian context. World customs journal. 2016. V.10, N. 1, pp. 35-44.

9. Risk management: an upgraded version of the nCEN now available. WCO News. 2018. N 80, pp. 14-15. URL: https://mag.wcoomd.org/uploads/ 2018/08/wco_news_80.pdf (access date: 27.02.2021). 
10. Using the New Computerised Transit System (NCTS) to move goods. URL: https://www.gov.uk/guidance/using-the-new-computerisedtransit-system-to-move-goods-across-the-eu-and-efta-countries (access date: 27.02.2021).

11. Ukraine has taken another step towards the implementation of a common transit procedure. URL: https://eba.com.ua/en/ukrayina-zrobylashe-odyn-krok-do-zaprovadzhennya-rezhymu-spilnogo-tranzytu-ncts/ (access date: 27.02.2021).

12. Some issues of granting permission for the use of special transit simplification : Resolution from 12 August, 2020, N 705 / Cabinet of Ministers of Ukraine URL: https://www.kmu.gov.ua/npas/deyaki-pitannyanadannya-dozvolu-705 (access date: 27.02.2021).

DOI https://doi.org/10.30525/978-9934-26-045-2-29

\title{
СТАЖУВАННЯ ДЕРЖАВНИХ СЛУЖБОВЦІВ НА РОБОЧОМУ МІСЦІ ЯК ІНСТРУМЕНТ УПРАВЛІННЯ ТАЛАНТАМИ. ДОСВІД ДЕРЖАВНОЇ МІГРАЦІЙНОЇ СЛУЖБИ УКРАЇНИ
}

\author{
Селіванов С. В. \\ кандидат наук з державного управління, \\ начальник \\ Управління персоналу Державної міграџійної служби Украӥни \\ м. Київ, Україна \\ Кашлакова А. I. \\ аспірантка кафедри публічної служби та публічного управління \\ Національної академї державного управління \\ при Президентові Украӥни, \\ завідувач сектору «Навчально-методичний центр» \\ Державної міграчійної служби Украӥни \\ м. Київ, Україна
}

Управління талантами - це спроба спрогнозувати, які людські ресурси необхідні для організації та створити умови для їх своєчасного залучення. Сили, які рухають управлінням талантами, мають два глибоких прояви. По-перше, влада перейшла від організацій до персоналу, тобто, тепер у талановитих людей більше суттєвих важелів, 